\section{India awards science portfolio to advocate of nuclear arms}

[New DelHI] Murli Manohar Joshi, a physicist, has been appointed cabinet minister for education and science and technology in India's new coalition government led by the Bharatiya Janata Party (BJP). Joshi, 64, believes in modernizing India through indigenous rather than imported technologies, and has also demanded that India should develop nuclear weapons.

The BJP won the largest number of parliamentary seats in the recent elections. The party is not known as a supporter of large-scale or expensive scientific projects, but this is the first time that the science portfolio has been given to a minister of cabinet rank; in the past it was handled by a junior minister.

It is also the first time that education and science portfolios have been allocated to the same minister. Assisted by a minister of state, Joshi - former professor of physics at Allahabad University and a past president of BJP - will look after all scientific departments apart from space and atomic energy. These, as in the past, will remain the direct responsibility of the prime minister, Atal Behari Vajpayee.

Vajpayee's national agenda says that his government "will re-evaluate the nuclear policy and exercise the option to induct nuclear weapons". Whether this means India will start building nuclear weapons is unclear.

But Rajagopala Chidambaram, chairman of the Atomic Energy Commission (AEC) and a key figure behind India's first nuclear test in 1974, has said that the country "has the technical capability" to do so. A former chairman of the AEC, Raja Ramanna, was also quoted recently in the Times of India as saying that India should go nuclear.

Neighbouring Pakistan says the BJP's nuclear policy is extremely worrying. Tariq Altaf, a spokesman for Pakistan's foreign office, said last week that Pakistan would be reviewing its policy of "nuclear restraint". He called on the international community to "take serious note of India's intentions". Pakistan is widely believed to be able to make nuclear weapons. Both India and Pakistan have refused to sign the Comprehensive Test Ban Treaty.

Strategic analysts fear new economic and foreign policy pressures for India. But Vajpayee says the new government will not go back on India's commitment to the World Trade Organization (WTO), including proposed changes to its patent law. Although contractual obligations would be met, he says, the government "would do some hard bargaining at WTO to ensure that national interests are better served". KS Jayaraman

\title{
New Zealand's universities face 'privatization' bid
}

[SYDNEY] Radical proposals from the New Zealand government for turning universities into private bodies fully exposed to market forces, and with all academics designated as either teachers or researchers, have generated fierce criticism from the academic community.

The idea was floated in a green paper (discussion document) last year. The government argues that the changes are needed to improve the effectiveness with which universities are run, and to ensure that they meet social and economic needs. It used the same argument when it created Crown Research Institutes out of the former Department of Scientific and Industrial Research (see Nature 391, 426; 1998).

But the country's Association of University Staff (AUS) has obtained the backing of 16 international affiliated organizations in a resolution to "condemn" the government for its "efforts to convert universities into business entities".

The International Conference of University Teacher Organizations (ICUTO) will shortly place New Zealand on a 'grey list' to alert academics contemplating taking a job at, or cooperating with, a New Zealand university to what it describes as "the deterioration of working conditions, collegial governance and academic freedom".

The main focus of discontent is a proposal to transform the management of universities from self-governing councils, with strong academic representation, into companies ruled by boards appointed by government to ensure compliance with "national goals".

Bryan Gould, chair of the New Zealand Vice-Chancellors' Committee and vicechancellor of the University of Waikato, says it is "inappropriate and virtually unparalleled in the advanced world" to treat universities as private-sector corporations. "Their purpose is not to make profits for shareholders but to serve wider and longer-term aims."

The vice-chancellors' committee says that "restrictive government controls would be seen within New Zealand and abroad as

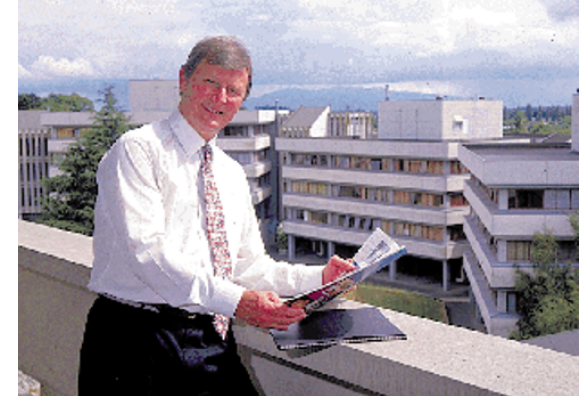

Gould: universities serve wider and longer-term aims than making profits for shareholders. undermining the autonomy of institutions and their role as critic and conscience of society". The green paper suggests that the role of critic should be "relaxed".

Jane Kelsey, AUS academic vice-president and professor of law at the University of Auckland, says that publicity through ICUTO could generate an international test case, as 60 per cent of New Zealand university staff are recruited from overseas.

The impact of the government's proposals on the quality of research and teaching figures high among concerns expressed in submissions from five major science and academic bodies. The most controversial notion is the option of splitting academics into teachers and researchers, each with distinct sources of funding.

To achieve this, officials are suggesting that funds covering research and researchbased teaching - estimated by the vicechancellors' committee to be about 30 per cent of 'blockgrants' - should be transferred to a competitive fund run by the government.

Critics of such a move include the Royal Society of New Zealand, which attacks the review's "regard [of] education and knowledge merely as tradeable commodities", and opposes the proposed financing of universities through student demand expressed through portable 'vouchers'. The society predicts that this would favour subjects leading to "personal gain and perceived status", to the detriment of science.

The government is already moving to allow some polytechnics to apply to become universities. The green paper suggests giving private and overseas institutions equal access to funding through student vouchers. Universities are worried that such a move could cut their funding.

George Petersen, president of the academy council of the Royal Society of New Zealand, points to the 1990 Education Act's clear definition of a university as including research interwoven with teaching. "The paper contradicts this by seeming to drag universities and polytechnics to a lowest common denominator," he says.

There has also been criticism from the government-financed and appointed Foundation for Research Science and Technology.

The government had said that, once comments on the green paper were assessed, a white paper (policy document) would be published later this year. However, a senior official indicates that this may not happen and universities are concerned that, if the government bypasses this stage, decisions on the reforms will emerge piecemeal, starting with the budget in late May.
PeterPockley 